Vol. 4, No. 1, 2019

\title{
SCIENTIFIC PRIORITIES OF THE DEVELOPMENT OF ENVIRONMENTAL RESEARCH IN KYIV NATIONAL UNIVERSITY OF CONSTRUCTION AND ARCHITECTURE. THE LIFE PATH OF PROFESSOR VOLOSKHINA O. S.
}

\author{
Tetyana Tkachenko \\ Kyiv National University of Construction and Architecture, \\ 31, Povitroflotsky Avenue, Kyiv, 03037, Ukraine \\ tkachenkoknuba@gmail.com
}

https://doi.org/10.23939/ep2019.01.019

Received: 04.02.2019

(C) Tkachenko T., 2019

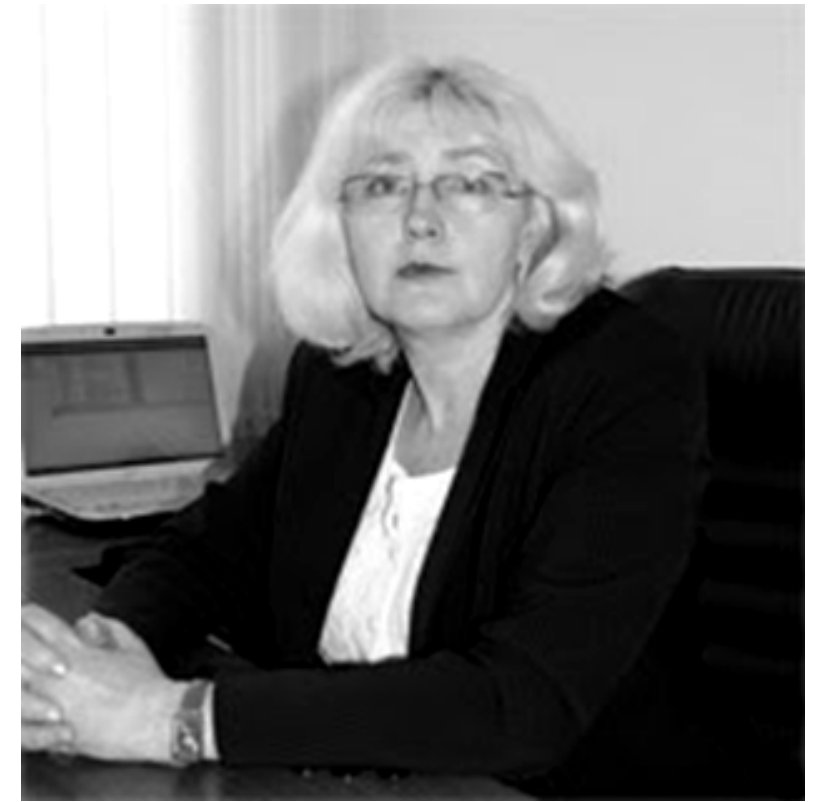

Abstract. The article deals with the main scientific priorities of the development of environmental research in Kiev National University of Construction and Architecture under the leadership of the Head of the Department of Labour Protection and the Environment, Doctor of technical sciences, Professor Voloshkina O. S. Current priorities of her scientific research are: management of ecological safety of atmospheric air in the area of motorway overpasses and formation of photochemical smog; increase in the environmental and energy efficiency of "green building"; introduction of "green structures" into the domestic construction in urbocenoses during the reconstruction and construction of residential and industrial premises; ecological issues in the construction industry.
Key words: ecological safety, atmospheric air, motorway overpasses; photochemical smog, green building, urbocenosis, green structures.

Voloshkina Olena Semenivna is Doctor of technical sciences, Professor, the Head of the Department of Labour Protection and Environment (since 2015 Honorary Professor of KNUBA). In 1977 she graduated from Moscow Engineering and Construction Institute, specializing in hydraulic engineering. From 2007 to 2015 she was the Head of the Faculty of Engineering Systems and Ecology, which was named the SanitaryTechnical Faculty until 2014. Professor Voloshkina O. S. is the author of about 145 scientific works, including tutorials, two patents for inventions and a monograph "Issues of Environmental Safety of Surface Water Objects" (2007). She is the Head of the Specialized Scientific Council of KNUBA D26.056.07 for the defence of Ph.D. and doctoral dissertations in the specialties 05.23.04 "Water Supply, Sewerage", 05.23.03 "Ventilation, Lighting and Gas Supply"; the member of the Specialized Scientific Council of the KNUBA in the specialty D26.056.05 "Environmental Safety".

Professor Voloshkina is editor-in-chief of the collection of scientific works of the KNUBA and ITGIP of the National Academy of Sciences of Ukraine "Ecological Safety and Nature Management", the member of the editorial board of foreign publications of USEFUL ACADEMY, published by SVV4U, MIAMI, FL, 33130, www.http: /useful.acade (USA), "Civil and Environmental Engineering", Byalostok University of Technology, www.biswbis.pb.edu.pl (Poland) and the 
national professional collection "Environmental Problems" (Lviv Polytechnic National University). Olena Voloshkina is an Honorary Professor of Shenyang University (China), Corresponding Member of the Academy of Engineering Sciences of Ukraine, the member of the methodical sub-commission of the Ministry of Education of Ukraine dealing with the development of the standards of specialty 101 "Ecology" in the field of knowledge 10 "Natural Sciences". Under her guidance, three Ph.D. and one doctoral dissertation in the specialty "Ecological Safety" were defended.

The range of her scientific interests is the study that allows making assessment and forecast of the formation of the quality of environmental components, management of environmental safety of territories and water areas, assessment of environmental risk and effect on the health of the population.

For the recent years, a number of scientific directions have been actively developing with the participation of young scientists at the Department of Labour Protection and Environment headed by Professor Voloshkina O. S. One of these directions is management of environmental safety of atmospheric air in the area of motorway overpasses and the formation of photochemical smog.

The choice of the direction of research is due to the fact that recently, in large industrial cities of the world and, in particular, in Ukraine, as a consequence of pollution of the atmosphere, a negative phenomenon, such as formation of photochemical smog, has become more frequent. The main factors and mechanism of smog formation in large cities of Ukraine have not been studied enough. Formaldehyde is one of the main factors of smog appearance over motorway overpasses in neutral meteorological conditions, as a product of oxidation of hydrocarbons from the emission of exhaust gases of various types of automobile engines and natural factors (hydrocarbons of vegetable origin). For the city of Kiev, the average daily concentration of formaldehyde in summer may be several times higher than the sanitary-and-hygienic standard, as evidenced by the data of the Central Geophysical Laboratory of the Ukrainian Hydrometeorological Centre. The dynamics of smog formation has been studied for a long time on an example of its formation in Los Angeles, London, Sydney and other major metropolises of the world. According to the World Health Organization, in urban air, under adverse weather conditions or with intensive traffic, the concentration of formaldehyde may reach $0.1 \mathrm{mg} / \mathrm{m}^{3}[1-3]$.

The dynamic block of the model is based on the assumption that a warm dome of contaminated air is formed over a motorway overpass. At this stage, the equation of the amount of motion of the contaminated air is solved, which allows determining the main parameters of the contaminated jet and calculating the amount of heat coming from the warm source into the environment, as well as nature and parameters of the convective jet [4]. The scheme of free convective jet is presented in Fig. 1. In this scheme $K$ is the second amount of motion which passes through the section of the jet at a distance $\mathrm{Y}, \mathrm{m}$, from the surface of the motorway overpass; $\mathrm{H}$ is the height of the convective jet from the source of heat; $\mathrm{V}$ is the rate of warm air, $\mathrm{m} / \mathrm{s}$; $\mathrm{A}_{\mathrm{r}}$ is the Archimedean power; $\mathrm{D}$ is the initial conditional diameter of the warm surface, $m$ (Fig. 1).

The second block of the model relates to the photochemical transformations of hydrocarbons $\left(\mathrm{C}_{\mathrm{x}} \mathrm{H}_{\mathrm{x}}\right)$ of different origin which are described in detail in a series of papers [5, 6], for example, methane, hydrocarbons of biogenic origin - isoprene and alkenes that are part of the emission of internal combustion engines.

Based on the developed mathematical model and the calculator of estimation of atmospheric air pollution of urbocenoses, depending on the climatic conditions and the amount of hydrocarbon emissions in motorway overpasses, it is possible to search for optimal managerial decisions at the municipal level for a number of scientific and practical tasks of the city [7]. These tasks include:

- estimation of greenhouse gas emissions from motor vehicles;

- impact of the city's emissions data in the context of global climate change;

- assessment of the rate of environmental safety of the urban environment and risk for the health of the population, especially at the boundary of residential development;

- development of the normative base and technological decisions concerning the measures of mitigation of the consequences of climate change and improvement of the air quality;

- development of plans and concepts of social and economic development of the city

The second actual direction of the research is devoted to the issue of increasing the environmental and energy efficiency of "green building" and introducing "green structures" into domestic construction in urbocenoses during the reconstruction and construction of residential and industrial premises. These issues are currently being solved at the Department by Professor Voloshkina O. S. and her colleagues - Professors Tkachenko T. M. and Krivomaz T. I. 


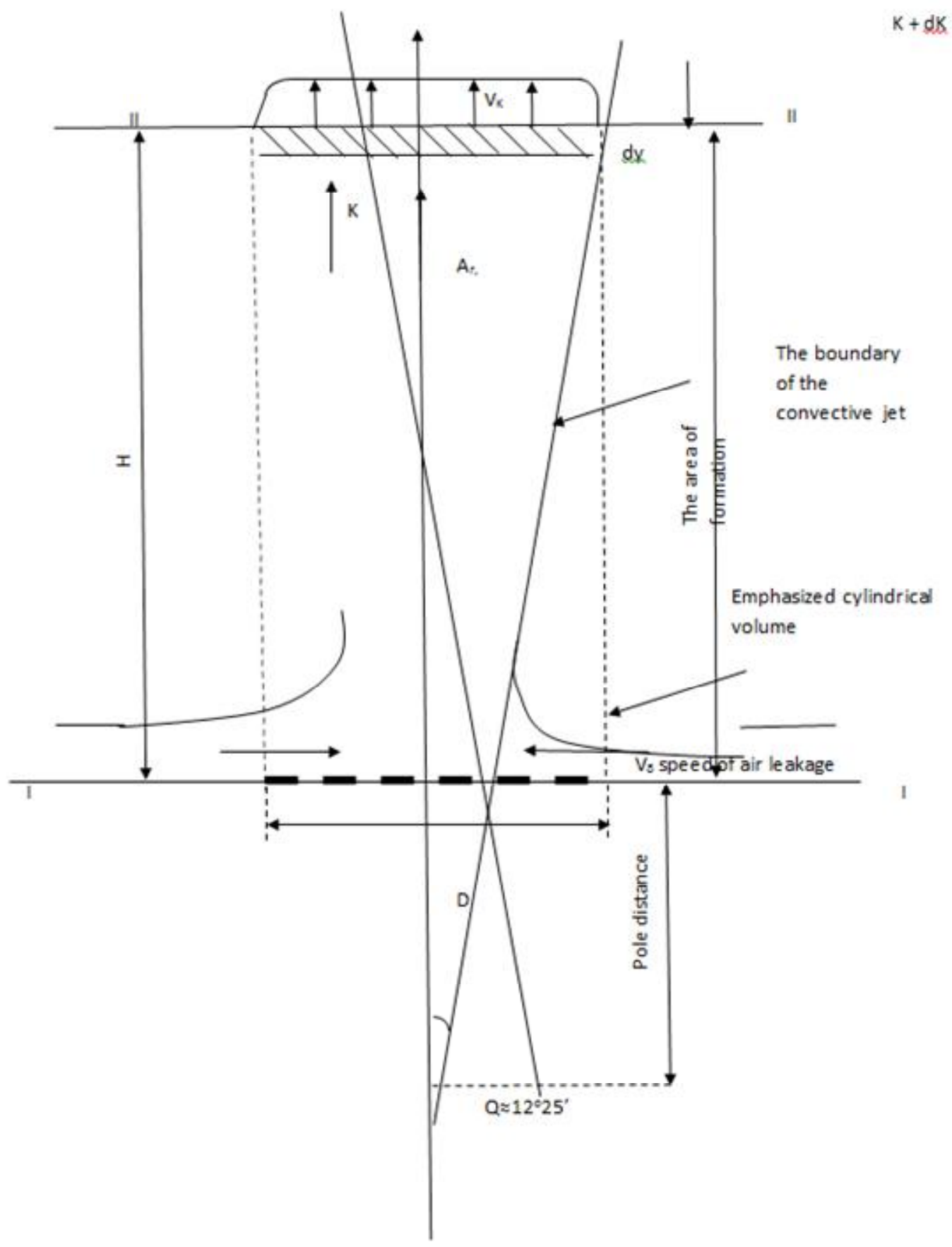

Fig. 1. Scheme of a free convective jet over a heated surface of a motorway overpass in neutral meteorological conditions

The analysis of the existing concepts of "green building" based on sustainable development has proved the need to find new methods and technical solutions for increasing energy efficiency of buildings, implementation of "green structures" and development of the domestic normative base in this direction.

Tkachenko T.M. is engaged in the research on raising the level of environmental and technogenic safety of urbocenoses through the development of scientific and methodological foundations for the creation of effective green structures in "green building". These studies include:

- the mathematical model of the development of the transformed ecosystem based on the long experience and observing the "green roof" from domestic materials in the conditions of the moderate continental climate of the southeast of Ukraine, which makes it possible to develop recommendations for a species set of plants for the preservation and artificial replenishment of urbancenosis biodiversity; 
- the method of experimental determination of the thermal resistance and the "cooling effect" of the plant layer separately from other layers, which takes into account significant unevenness of the thermophysical properties and variable air velocity, which allows to increase the energy efficiency of buildings with "green structures", as well as certify the vegetative layers;

- the scientific and methodological bases of the concept of sustainable development of urbocenoses has been improved due to the reduction of technogenic influence on the biosphere by introducing energyefficient low-carbon "green structures" into the "green building" system;

- the method of forecasting and estimating the level of sequestration of $\mathrm{CO}_{2}$ by biomass of "green structures", which allows to increase the biocapacity of urbocenoses and reduce their ecological impact;

- further development of the interpretation of the concept of "cooling effect" of plants as the temperature difference between the ambient air and the surface under the plant layer in the absence of heating or cooling under this layer, which allows to determine the properties of the plant layer most accurately (Fig. 2).

At the present stage, when Ukraine is carrying out modernization of educational activities in the context of European requirements related to the development of European higher education, the main task of the Department is to increase the overall level of education of future specialists of all specialties at the appropriate departments of the University.

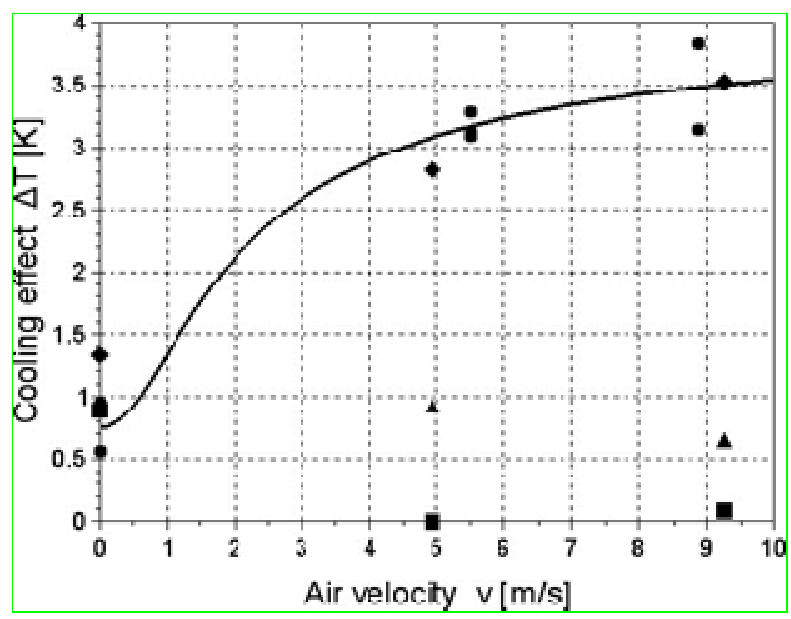

Fig. 2. The dependence of the "cooling effect" on the air velocity:

- - grass height is 40 and $123 \mathrm{~mm}$, different points;

$\Delta$ - grass height is $399 \mathrm{~mm}$, around the centre of the model;

- - grass height is $399 \mathrm{~mm}$, the angle with the windward side;

- - grass height is $399 \mathrm{~mm}$, the angle from the winding side.

Ecologization in the construction industry means taking into account environmental requirements and aspects in construction norms and standards; dissemination of environmentally friendly design decisions; environmental cleanliness of the industry of building materials, structures and building production; increase in ecological reliability and safety of engineering systems and structures; environmental efficiency of construction management.

Ukraine has included the international standards of ISO into the system of national standards, among which the following ones can be noted:

- Environmental Management Systems (DSTU ISO 14001 - 2006;

- Guidelines for the implementation of environmental audit (DSTU ISO 14010, 14011, 14012);

- Environmental management. Life Cycle Assessment LCA (DSTU ISO 14040...14043) and others.

The content and requirements of the standards should be implemented into the construction industry standards (DBN system), namely: creation of separate annexes to the existing DBNs related to the establishment of environmental management systems in the construction industry from construction and installation departments to construction corporations; guidelines for the development of technical documentation for evaluation of the life cycle of various phases of the construction process, from raw material extraction to waste processing, elimination of construction objects and elements of infrastructure.

The development and introduction of the model of "clean production" into the construction involves creation of an integrated strategy for preventing environmental pollution by production, products and services. The strategy includes: control over energy and resource consumption; reduction of emissions, discharges, waste; minimizing the health risks for people and the environment [8].

In the construction industry, high rates of economic growth are possible only with the formation of a new development model - green recovery, green growth, green development, green technologies and environmentally safe production. In accordance with the Strategy of low carbon development of Ukraine until 2050, just these directions are emphasised in scientific developments of Professor Voloshkina O.S. and the Department of Labour Protection and the Environment. These developments are aimed, first of all, at reducing emissions of greenhouse gases and improving the quality of life of the population in urban areas.

\section{References}

[1] Gerd, A., Folberth, Timothy, M., Butler, William, J., Collins, Steven, T., Rumbold (2015) Megacities and climate change- A brief overview. Environment Pollution. 203, 235-242. 
[2] Richard C. Flagan,John H. Seinfeld.(1988). Fundamentals of air pollution engineering. California Institute of Technology, by Prentice-Hall, Inc. A Division of Simon $\&$ Schuster, Printed in the United States of America. P. 542.

[3] Sipakov R. V. Assessment and forecast for the creation of photochemical smog over transport overpasses in Kyiv / Sipakov R. V., Trofimovich V. V., Voloshkina O. S., Bereznitskaya Y. O. // Prob. Scientific works "Ecological safety and nature management", KNUBA, ITGIP NANU, K., 2018.-issue 25 p. 44-51.

[4] O. S. Voloshkina. Convective Model of Emission Distribution on the Road Overpass Under Neutral Weather Conditions / O. S. Voloshkina, V. V. Trofimovich, I. V. Klimova, R. W. Sipakov, T. M. Tkachenko // Prob. Scientific works "Ventyliatsiia, Osvitlennia Ta Teplohazopostachannia” KNUBA, K., 2018.-issue 27 p. 23-33.

[5] John, H., Seinfeld, Spiros, N., Pandis. (1997). Atmospheric chemistry and physics. A WileyInterscience Publication, Printed in the USA, QC879.6. S45. - 1356 P.
[6] V. V., Trofimovich, O. S., Voloshkina, M. M., Fandikova, I. V., Klimova, N. E., Zhuravska. (2012). Monitoring of atmospheric air. Problems of modeling and forecasting. Prob. Scientific works "Ecological safety and nature management", KNUBA, ITGIP NANU, K., 10,102-120.

[7] R. Sipakov, Pollution of atmospheric air above the city highways. R. Sipakov, O. Voloshkina, D. Varavin, Y. Ampilova, T. Krivomaz, J. Bereznitska / USEFUL online journal, vol. 2, no. 4, pp. 01-08, December 2018. https://doi.org/10.32557/useful-2-4-2018-0001

[8] Voloskhina O. S., Trofimovich V. V. Osoblyvosti ekologichnoy pidgotovki fachivciv vichoi osvityi u vidpovidnosti do Strategii nyizkovuglerodnogo rozvitku Ukraini do 2050 roku/Kolektivna monografiy za materialami XYII Mijnarodnoy naukovo-praktichnoi konferenzii "Informaziyni technologii upravlinny ecologichnoyu bezpekoyu, prirodokorustuvannyam, zachodami $\mathrm{v}$ nadzvichainich situacijach: rozrobki ta dosyagnennya do 100-riccya NANU" (24-25 veresnya 2018 p.)., Kijv: TOV "Vidavnictvo "Juston", 2018. 156-158 p. 